in which Mr. Arthur Nicols, speaking from recollection, says that "Teredo navalis is certainly able to endure a long continuance of freshwater. At Brisbane the river is subject to freshes, one of which lasted ten days, when the flood was so powerful that ocean steamers could not get up. Salt-water is said at floods to ascend thirty miles beyond the town, which is itself twenty-five miles from the Pacific,--but the ebbs are more fresh than salt. Piles bave to be protected with Muntz metal."

It will be seen that more definite information is required on all the points raised. There is said to be a freshwater Carcharias in the rivers of Fiji, and it would be interesting to learn whether it also ever lives wholly beyond the tidal reaches, or merely ascends rivers, as seals will, in search of food.

It thus appears, so far as we can go at present, that Teredo chiefly flourished during our Eocene time in waters that were clearly estuarine. The purely salt water reaches of the great river, such as those in which the London Clay and Bracklesham beds were deposited, were less favourable to its development than the almost fresh-water reaches in which the Bournemouth fresh-water beds and the Lower Bagshot of the London Basin were formed. In this last class of deposits there is no other sign whatever of aquatic life, either fresh or salt, and we are forced to conjecture that perhaps frequent change from quite fresh to quite salt water was the excluding cause. In what were perbaps more littoral marine beds, out of the influence of the river, such as those of Herne Bay and Highcliff, the Teredo seemed comparatively to languish, and it is quite excluded from the higher reaches of the river in which the Lower Bagshots of Studland and Corfe were formed, and which from the presence of Unio would appear to have been wholly freshwater. It had no place in the lacustrine deposits of Headon and Bembridge, and even the brackish and salt waters of these formations seem to have been quite unfavourable to it, being, it appears, from their teeming life, too permanently either fresh or salt. Without its presence we might never have suspected that many important masses of sediment containing terrestrial vegetation had ever been formed within the influence of the tides of the sea. Sufficient has been said to illustrate the peculiar local significance that the record of this destructive molluse may possess with regard to the origin of a formation. It is noteworthy that the Eocenes possess three distinct types of Teredo which have not as yet been distinguished.

\title{
NOTICES OF MEIMOIES.
}

I.-Report on the Geology uf the Krmberley District, Western Australia. By Edward T. Hardian, etc., of H. M. Geological Survey of Ireland. Fcap. pp. 22, 16 Plates, Map. (Perth, W.A., 1884.)

THE country described in this very excellent report comprises that 1 portion of Western Australia extending from Roebuck Bay 
inland to the Leopold Ranges, and between Port Usborne, and a line running eastward to the south of the Fitzroy River (lat. $16^{\circ} 35^{\prime}$ and $18^{\circ} 30^{\prime}$ S., long. $122^{\circ} 10^{\prime}$ and $126^{\circ} 50^{\prime} \mathrm{E}$.), including in all 12,800 square miles.

It may be generally described as a vast undulating plain, rising gradually from the sea-coast to a height of $200 \mathrm{ft}$, broken by isolated hills and some extensive mountain ranges, the highest reaching $2000 \mathrm{ft}$. above the sea-level. The district is unusually well watered, The geological formations represented over this immense tract of country consist of Recent accumulations, Pliocene sand and gravels, Carboniferous sandstones, grits, and limestone, and Metamorphic rocks.

The Recent accumulations are-(a.) Wide sand-flats locally termed "Marshes," along the sea-coast, and extending inland for miles, the most striking instance being the great plain from Roebuck Bay to Barlee Spring. The contained fossils are of recent species. (b.) Alluvium deposited by successive floodings of the rivers, estimated as equal to 3355 square miles, or $2,147,200$ acres. But taking into consideration an average thickness of $30 \mathrm{ft}$., we have the "enormous weight of $103,924,480,000$ tons of silt and mud carried down by these rivers" of the Kimberley District. (c.) River-gravels accumulated in the upper reaches of many of the streams (notably in the Usborne district), the pebbles often reaching six to nine inches in diameter. These subdivisions comprise the "Recent" formations described by Mr. Hardman.

Certain deposits of reddish sand, with small pea-like nodules of ironstone, and other rocks, with beds of red and yellow-ochreous earth, are provisionally classed as Pliocene. They are termed the "Pindan" sands and gravels, and occupy a very large area, and have been proved to be at least 30ft. in thickness. They are unfossiliferous, "but there can be little question that they are of comparatively recent age."

The Carboniferous rocks appear to be separable into an upper and lower series. The upper consists of sandstones, and forms the chief mountain ranges, extending as much as $\mathbf{1 9 0}$ miles into the interior, and are over $1000 \mathrm{ft}$. in thickness. Lepidodendron, Calamites, and Sigillaria are said to occur in these beds, but no traces of coal have been met with. The apparently overlying Carboniferous Limestone extends in a line N.W. and S.E. directly across the Kimberley district, with a maximum breadth of thirty miles, and an estimated thickness of $1000 \mathrm{ft}$. "It is a light-coloured, compact, brittle, splintery, more or less Magnesian Limestone," and bears a strong resemblance to the Upper Carboniferous Limestone of Ireland. It is in places very cavernous. Fossils were met with abundantly at certain localities, and the list of species given by Mr. Hardman clearly bears out the age assigned to the beds.

The Metamorphic rocks are divided into two classes - the schistose, including gneiss schist and metamorphic granite, and quartzites and altered grits. The former are widely developed along the base of the Leopold Range, and contain quartz veins, and the common garnet 
in great abundance. The quartzites and altered grits constitute the mountainous country in Kimberley, and are interstratified with red and yellow sandstones, conglomerates, and grits.

Dykes of felstone, of later age than the Metamorphic rocks, are also met with. No precious metals were discovered, but Mr. Hardman believes in their discovery being probable in this series.

The Report is accompanied by sixteen geological views, and a very good map.

\section{II.-The Lias of Fenny Compton, Warwickshire.}

$\mathrm{M}$ R. THOMAS BEESLEY, F.C.S., has just issued this paper with additions and corrections to the end of 1885 . 'The author describes the situation of Fenny Compton as a little station on the Great Western and East and West Junction Railways, on the Warwickshire side of the boundary between that county and those of Oxford and Northampton, eight miles from Banbury and twelve from Leamington, and at an elevation of nearly 400 feet above the sea. He points to the Burton Hills, whose bold escarpment forms so pleasing a feature in the landscape, as the extremity of the Marlstone promontory which stretches from the Cherwell valley into the Lower Lias bay of Warwickshire. He then directs attention to the sources of the Leam, the Cherwell, and the Nene, flowing respectively to the Severn, Thames, and Ouse, which sonrces are all within a circle of one mile radius, in the high ground above the Marlstone escarpment of Northamptonshire, a short distance east of the Burton Hills. The railway at Fenny Compton passes for nearly three-quarters of a mile through a cutting which exposes a section of the lowest zone of the Middle Lias, which, with the exception of those on the Dorsetshire and Yorkshire coasts, is probably the most extensive to be met with in England. The zone of Ammonites Jamesoni which occurs at Fenny Compton is, with the two others next above it, referred to the Lower Lias in the maps and memoirs of the Geological Survey of England; but, under the circumstances, the author prefers the continental arrangement. Proceeding southwards upon the East and West Junction line, the banks rise rapidly, exposing a bluish-black shale, fine in texture and rather marly. With one doubtful exception, none of the Ammonites of the Lower Lias have been found there. Some geologists have attributed this bed, and a good deal above it, to the "Raricostatus zone" of the Lower Lias, but Professor Tate, who had carefully examined it, agreed with the author that there was an error in the conclusion.

The bed soon presents unmistakable Middle Lias characteristics in the form of parallel lines of pale grey or reddish flattened nodules. They are much more calcareous than the clay in which they are embedded, and contain a notable amount of phosphoric acid, chiefly combined with line. There are five lines of conspicuous nodules in the 40 feet of shale. The lower nodules, like the shale in which they lie, are rather poor in fossils, though both become richer in higher ground. The author possesses a small one containing on its surface 50 specimens belonging to more than 20 species, one of which 
is a Discina. About a quarter of a mile from the station, two noticeable bands of stone occur about 40 feet above the base of the section. The upper stone is separated from the lower by $4 \mathrm{ft}$. 6 in. of dark blue clay with many fossils. It is of the same mineral character and appearance as the lower; but contains corals of the genus Montlivaltia, while corals are no longer present in the lower. The Spiriferince, which play so important a part in the fauna of the upper stone band, as well as the corals and Waldheimia numismalis, are absent from the Yorkshire Lias. The dip of the beds is distinctly to the south, as the stone bands sink below the surface, at a distance of about a third of a mile beyond the spot where they first appear. The true dip is about three-fourths of a degree. Above the stone bands, the shale gradually becomes greyer, rougher, and more lumpy, many of the lumps containing impressions of fucoids.

The following is a detailed section of the Fenny Compton beds:-

Rough shaly clay...

$\begin{array}{llllllllllllll}\text { Band of calcareo-argillaceons nodules } & \ldots & \ldots & \ldots & \ldots & \ldots & \ldots & \ldots & \ldots & 20 & 0\end{array}$

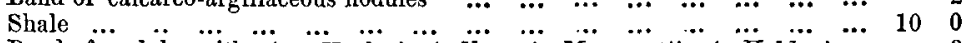

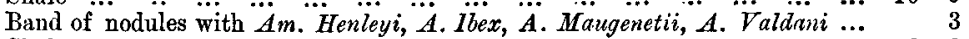

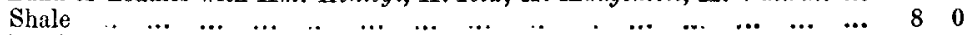

Band of nodules with Am. Margenetii, and Fucoids $^{\ldots}$..

$\begin{array}{lllllllllllllll}\text { Shale, with Belemnites } & \ldots & \ldots & \ldots & \ldots & \ldots & \ldots & \ldots & \ldots & \ldots & \ldots & \ldots & 2 & 0\end{array}$

Rough, shelly, argillaceous limestone, with $A m$. Valdani, and A.Jamesoni, Spiriferina verrucosa, Belemnites clavatus, Lima Hettangiensis, Waldheimia

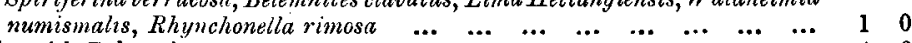

$\begin{array}{lllllllllllllll}\text { Shale, with Belemnites } & \ldots & \ldots & \ldots & \ldots & \ldots & \ldots & \ldots & \ldots & \ldots & \ldots & \ldots & 4 & 6\end{array}$

Rough, shelly, argillaceous limestones with $\dddot{A} m$. armatus (young). Pecten priscus, Limea acuticosta, Gryphas obliquata, Cardinia attenuata, $\begin{array}{llllllllll}\text { Rhynchonella rimosa. Corals } & \ldots & \ldots & \ldots & \ldots & \ldots & \ldots & \ldots & \ldots & \ldots\end{array}$

Shale

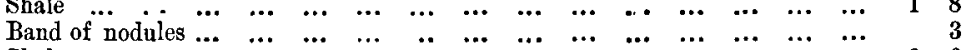

$\begin{array}{llllllllllllllllll}\text { Shale } & \ldots & \ldots & \ldots & \ldots & \ldots & \ldots & \ldots & \ldots & \ldots & \ldots & \ldots & \ldots & \ldots & \ldots & \ldots & & 3\end{array}$

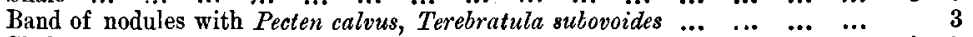

Shale $\ldots \begin{array}{lllllllllllllllll} & . . & \ldots & \ldots & \ldots & \ldots & \ldots & \ldots & \ldots & \ldots & \ldots & \ldots & \ldots & \ldots & \ldots & 14 & 0\end{array}$

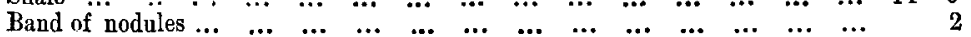

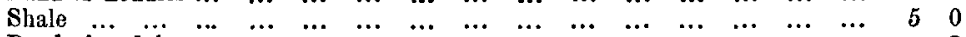

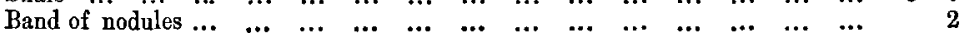

$\begin{array}{lllllllllllllllll}\text { Shale } & \ldots & \ldots & \ldots & \ldots & \ldots & \ldots & \ldots & \ldots & \ldots & \ldots & \ldots & \ldots & \ldots & \ldots & \ldots & \ldots \\ \end{array}$

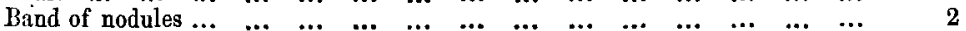

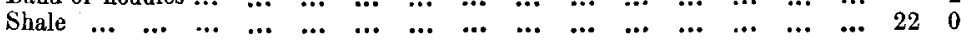

III.-AnNa LeEN Des K. K. NAturhistorischen Hofmuseuma ; REDigirT von Dr. Franz RitTer von Hauer. Band I. No. 1. Jahresbericht für 1885, von Dr. F. von HAUER. (Wien : 1886.)

Annals of the Royal Natural History Museum. Edited by Dr. F. von Hauer. Vol. I. No. 1. Annual Report for 1885, by Dr. F. von HAder. (Vienna : 1886.)

7 IHIS report contains a review of the progress made in the organization of the New Natural History Museum of Vienna under the superintendence of the well-known mineralogist, Dr. von Hauer, the successor of the late Dr. F. von Hochstetter. Until lately, the 
various Natural History collections of the Austrian capital were deposited in different buildings, under independent management, but they have now been brought together in a magnificent edifice expressly constructed to receive them. The Museum includes the following five divisions: (1) Zoological; (2) Botanical; (3) Mineralogical and Petrographical; (4) Geological and Palæontological; (5) Anthropological and Ethnographical. Dr. A. Brezina and Theodor Fuchs are the keepers of the third and fourth departments respectively. The mineralogical collection is noted more particularly for its meteorites, of which there are 1207 specimens from 365 different localities; and the special forte of the palreontulogical division is the splendid collection of Tertiary mollusca.

A special library is being formed in connection with the museum, and we notice with pleasure the facilities provided for carrying forward original research whether by the museum officials or by voluntary independent investigators.

The present number is intended as the first of a series in which it is proposed to publish, together with the museum report, original memoirs on various natural history subjects.

IV.-Die Crinoïden des norddeutschen Ober-Devons. Von A. von Kankn, in Göttingen. Neues Jahrbuch für Mineralogie, etc., 1886, Bd. I. p. 99-116, Plates I.-II.

WING to their defective state of preservation, very little has hitherto been known of the Crinoids of the Upper Devonian strata of North Germany. Prof. von Koenen in this paper gives the results of a critical examination of specimens which he has for many years been collecting, as well as of those preserved in the Museums of Bonn, Berlin, and Aix-la-Chapelle. From a comparison with the forms from the Famennien group of Senzeille in Belgium, described by Fraipont, the author has been able to determine the position of the anal plate and the composition of the ventral roof of the calyx of the different species; characters, which the author regards as of special value in the determination of species. The following species are described and figured:-Melocrinus gibbosus, Goldf., $\vec{M}$. hieroglyphicus, Goldf., M. Chapuisi, Dewalque, M. Dewalquei, n. sp., M. Benedini, Dew.-Fraipont, Hexacrinus infundibulum, n. sp., $H$. angulosus, n. sp., $H$. verrucosus, Dewalque, $H$. tuberculatus, n. sp., and Storthingocrinus sphericus, sp. $\mathbf{n}$.

G. J. H.

V.-Records of the Geological Surver of India, Vol. XIX. Part 1, 1886.

THIS part contains, with other papers, the Annual Report of the Geological Survey of India by Mr. H. B. Medlicott, in which attention is more particularly called to the discovery, by Dr. Warth, of Palæozoic fossils in the Salt Range of the Punjab, in strata, associated with a noted Boulder-bed, which have hitherto been regarded as belonging to the Cretaceous series. The fossils, which have been determined by Dr. Waagen, include several species of Conularia, Bucania, Nucula, Atomodesma, Aviculopecten, Discina and Serpulites, 
some of which occur in Carboniferous strata in Australia, and others are related to species from the Carboniferous Limestone of Belgium. A further interest attaches to this discovery of Carboniferous fossils in connection with the Boulder-bed in the Salt Range, from the probability that this bed may be jdentical with the Talchir boulder glacial deposits found almost everywhere at the base of the Gondwana rocks of Peninsular India. These in turn have been correlated with remarkable Boulder-beds, believed to be due to ice-action, occurring in the Carboniferous series of Australia. Mr. R. D. Oldham has lately visited Australia, and contributes, in this part, a highly important memorandum on the subject. This further evidence strongly supports the original views of Dr. Blanford as to the Palæozoic age of the Lower Gondwana deposits, and, as Mr. Medlieott remarks, "it would be the first clear and broad case to confirm the assertion, made twenty-five years ago by Prof. Huxley, when introducing the term 'homotaxis,' for it shows that a full-blown Mesozoic flora in one region of the earth was contemporaneous with a full-blown Palæozoic flora in another region."

Under "Afghan and Persian Field Notes," Mr. C. L. Griesbach, who accompanied the Afghan Boundary Commission as geologist, gives an outline sketch of the various geological formations, which range from the Post-Tertiary to the older Palæozoics, occurring in the Herat Valley and Khorassan.

The other papers in this part are "Notes on the Section from Simla to Wangtu," by Col. McMahon, and an excellent "Report on the International Geological Congress of Berlin," by Dr. W. T. Blanford, F.R.S.

G. J. H.

VI.-Contributions à la Géologie des Pays-Bas. Par Dr. J. Lorié. Résultats Gélogiques et Paléontologiques des Forages de Puits à Utrecht, Goes et Gorkum. Extrait des Archives Teyler, Series II. tom. ii. Large 8vo. pp: 132, and 5 lithographic plates. (Haarlem, 1885.) -

7 HE opportunities of studying the structure of the earth's crust 1 in a flat country like the Netherlands are indeed few and far between. There are no coast or valley sections, and owing to the general level character of the country, scarcely any artificial cuttings are required for the railways. Under such circumstances, wellsinkings afford the best, and almost the only means of ascertaining the stratigraphical succession. In the course of the last few years, three important sinkings have been made in this country, at Utrecht, at Goes on the island of South Beveland, and at Gorkum in South Holland. The first of these was carried to the depth of 369 mètres, that at Goes to $223.9 \mathrm{~m}$., and that at Gorkum to $182 \mathrm{~m}$. beneath the surface, which, in each case, did not exceed $5 \mathrm{~m}$. above the sea-level. The distribution and the characters of the fossils met with in these well-borings have been carefully investigated by Dr. Lorié, and this memoir contains critical descriptions and figures of the different species and tabular lists of their occurrence in the beds at different 
depths, and a comparison with those in strata of corresponding age in Belgium and East-Anglia.

The strata pierced in these well-borings consist entirely of beds of gravel, sand and clay, of Tertiary and Quaternary age, some barren of fossils, others with shells, bryozoa and other fossils. There are 131 species enumerated, all of which have been previously described. In the Goes boring the entire thickness of the Pliocene is penetrated. The Lower Pliocene or Diestien, the equivalent of the Coralline Crag, has a thickness of 37 mètres. It contains a certain proportion of Polyzoa and appears to have been deposited in a tolerably deep sea. It rests upon the Rupélien clay of Middle Oligocene age. The Upper Pliocene or Scaldisien, the equivalent of the Red Crag of East-Anglia, has a tbickness at Goes of between 23 and 29 mètres. Above this comes the so-called Diluvial beds, about 47 mètres in thickness. At Utrecht the Diestien beds have a minimum thickness of $125 \mathrm{~m}$. and their base is not reached. They are principally greyish-green sands with intervening bands of clay, and the absence of Polyzoa and the broken condition of the shells indicate a sballower sea than at Goes. The Scaldisien or Red Crag has a thickness of $82 \mathrm{~m}$., and there are above it beds of Quaternary and Recent age $162 \mathrm{~m}$. in thickness. At Gorkum the base of the Scaldisien or Red Crag was not reached at the depth of $182 \mathrm{~m}$. This deposit has thus a minimum thickness of $62 \mathrm{~m}$., and from the fragmentary and triturated shells therein, it appears to be of littoral origin. Above this are freshwater beds, $28 \mathrm{~m}$. in thickness, of Quaternary age. With the exception of the first $12 \mathrm{~m}$. of recent deposits, the intervening strata $80 \mathrm{~m}$ : in thickness are also of Quaternary age.

This memoir is a valuable contribution to the history of the later fomsiliferous strata in a new area, and it has a special interest to the student of the corresponding beds in East-Anglia.

G. J. H.

\section{正 $V I E W S$.}

I.-Bulletins of the United States Geological Survey. Nos. 1-19. (Government Printing Office, Wasbington, 1884-5.)

$\mathrm{T} \mathrm{N}$ addition to the large volumes of the Annual Reports, and the 1 magnificent Monographs, the United States Geological Survey are also issuing a series of Bulletins, each on a special subject and complete by itself. Nineteen of these papers have already been published. Some of them, it is true, treat of subjects which are but remotely connected with geological research, as, for instance, "Gold and Silver Conversion Tables," giving the coining value of Troy ounces of fine metal, etc., and "Boundaries of the United States and of the several States and Territories:" others, though not directly geological, are of great practical value to all geologists working in the United States and Canada, as, for example, "A Dictionary of Altitudes in the United States" and "Elevations in the Dominion of 